\title{
Meningkatkan kelancaran membaca anak SD terutama kelas 1 dengan metode $K \& V$
}

\author{
Istiqoma Helmi Putri \\ E-mail: istiqoma.helmi6854@student.unri.ac.id \\ *Program Studi Pendidikan Bahasa dan Sastra Indonesia, Universitas Riau
}

\section{Pendahuluan}

Kelas 1 SD merupakan gerbang bagi seorang anak memasuki dunia pendidikan formal. Jika guru salah mengajar atau menyampaikan ilmu maka akan berdampak dan berpengaruh pada pemahaman dan kemajuan siswa di masa yang akan datang. Salah satu pembelajaran awal bagi anak SD kelas 1 adalah membaca. Membaca merupakan suatu keterampilan mengenal dan memahami tulisan dalam bentuk urutan lambang-lambang grafis dan perubahannya menjadi wicara bermakna dalam bentuk pemahaman diam-diam atau pengujaran keras(Kridalaksana,1993:135). Ada banyak metode yang bisa dilakukan guru untuk membantu memperlancar anak kelas 1 SD membaca, salah satunya dengan metode K\&V (Kartu \& Vidio ).

Metode $\mathrm{K} \& \mathrm{~V}$ diterapkan kepada siswa diharapkan mampu mengenal dan hafal semua huruf. Tujuan penulis menginovasi pembelajaran membaca ini adalah karena masi banyak menjumpai anak SD yang belum hafal huruf atau lancar membaca terutama anak SD kelas 1, oleh karna itulah dirancang sebuah metode pembelajaran yang diharapkan dapat memberikan kemudahan kepada guru sebagai pendidik dan siswa sebagai peserta didik. Pembelajaran membaca yang menarik dapat membuat siswa/siswi tertarik dan suka belajar membaca, setelah mereka tertarik dan menyukai maka cepat atau lambat mereka akan mampu membaca dengan baik. 


\section{Pembahasan}

\section{A.Pengertian Metode K\&V(Kartu \& Vidio)}

Metode K\&V (Kartu \& Vidio) adalah suatu metode pembelajaran membaca yang dirancang sedemikian rupa untuk membantu siswa/i SD terutama kelas 1 . Tujuannya adalah untuk membantu memperkenalkan lambang lambang/huruf abjad kepada anak dan diharapkan bisa membantu memperlancar membaca anak. Metode ini mengandalkan kreativitas pendidik/guru dalam mengajar siswa. Semakin kreatif guru dalam menerapkan metode ini semakin besar pula kemunginan siswa berhasil menguasai,menghafal abjad dan bisa membaca. Selain kreativitas guru motivasi belajar siswa juga sangat penting sebab motivasi belajar yang positif akan mengarahkan siswa lebih tekun dalam belajar. Siswa akan berusaha mempelajari sesuatu dengan baik agar memeroleh hasil belajar yang baik pula. (Zulhafizh, Atmazaki, \& Syahrul, R. 2013). Maka dari itu peran guru sebagai pengajar dan pendidik harus pandai pandai dalam menyampaikan pelajaran semenarik mungkin agar siswa semangat mengikuti proses pembelajaran.

\section{B.Cara Pelaksanaan Metode K\&V(Kartu \& Vidio)}

Cara pelaksanaan metode membaca $\mathrm{K} \& \mathrm{~V}$ mudah saja. Metode ini disesuaikan saja dengan situasi dan kondisi sekolah. Kartu disini berupa huruf abjad yang dikemas sedemikian rupa dalam bentuk gambar dan warna yang beragam. Dan vidionya pendidik bisa menggunakan proyektor sekolah dalam menampilkan vidio animasi membaca. Setelah kartu dan vidio sudah ada, maka pendidik akan langsung mempraktekkan dengan cara membaca huruf abjad bersama sama dengan siswa baik itu dengan dinyanyikan atau sekedar membaca bersama tergantung pendidiknya. Setelah itu pendidik akan memberikan kartu tadi kepada siswa satu per satu, lalu siswa diminta untuk menyebutkan huruf yang ia dapat. Kemudian setelah semua sudah menyebutkan hurufnya, lalu pendidik akan menayangkan vidio animasi membaca baik itu huruf abjad, ejaan suku kata, kata hingga kalimat. Setelah penayangan itu siswa diminta untuk menyusun kartu yang dimiliki dengan temannya menjadi satu kata, tentunya dengan bimbingan guru/pendidik. 


\section{Tindakan yang Dilakukan}

\section{a. Menjalin komunikasi yang baik dalam pembelajaran}

Komunikasi perlu dibangun dengan baik antara pendidik dan peserta didik, sebab komukasi menjadi penentu bagaimana peserta didik mampu menerima dan mengolah informasi yang dia peroleh (Abdul Aziz,2017:180). Pendidik harus mempunyai Kemampuan menjalin komunikasi yang baik dalam pembelajaran agar informasi bisa tersampaikan kepada peserta didik. Inovasi juga diperlukan dalam proses belajar mengajar agar peserta didik tidak mudah bosan dan suka belajar.

\section{b. Memperkenalkan metode K\&V kepada peserta didik}

Setelah terjalin komunikasi yang baik antara pendidik dan peserta didik, selanjutnya pendidik akan memperkenalkan metode pembelajaran yang akan dipakai dan dilaksakan. Metode yang diangkat penulis adalah metode $\mathrm{K} \& \mathrm{~V}$. Seperti yang dijelaskan di atas Metode $K \& V$ (Kartu \& Vidio) ini adalah suatu metode pembelajaraan membaca yang melibatkan media kartu dan vidio yang mana metode ini dikhususkan kepada anak SD untuk membantu memperkenalkan lambang lambang/huruf kepada anak dan diharapkan bisa membantu memperlancar membaca anak.

\section{c. Menerapkan metode $\mathrm{K} \& \mathrm{~V}$ kepada peserta didik.}

Metode $\mathrm{K} \& \mathrm{~V}$ bisa diterapkan kepada peserta didik oleh pendidik, sebab metode ini tergolong mudah karna pendidik bisa menggunakan media yang sederhana tetapi menyenangkan bagi anak dan disesuaikan juga dengan kondisi sekolah. Kartu yang digunakan pendidik bisa dibuat sendiri dengan kreativ atau di print. Untuk vidio bisa menggunakan sarana yang ada disekolah seperti LCD proyektor, komputer, dan lain sebagainya, vidio yang ditampilkan berupa vidio animasi membaca yang banyak disukai anak. Karena sebagian besar berhasilnya penguasaan materi oleh peserta didik dipengaruhi oleh kemampuan pendidik atau guru menerapkan metode pembelajaran kreatif dalam menyampaikan informasi. 


\section{d. Memberikan kuis membaca Kepada peserta didik}

Memberikan kuis kepada peserta didik juga dapat membangkitkan semangat mereka. Walaupun dengan hadiah yang sederhana tetapi mereka akan kembali bergairah mengikuti pembelajaran, bukankah itu yang diharapkan pendidik kepada peserta didiknya? tentu saja iya. Dengan memberikan kuis mereka akan termotivasi untuk belajar meskipun mereka mengharapkan hadiah, tetapi cara itu bisa diterapkan pada anak untuk merefresh otak mereka.

\section{Sarana Pendukung}

a. LCD Proyektor untuk menampilkan vidio animasi;

b. Kartu berwarna-warni yang bertuliskan huruf/kata/kalimat;

c. Buku paket;

d. Catatan .

\section{Tindakan Solutif}

a. Jika tindakan dalam proses belajar mengajar terdapat kendala/masalah yang disebabkan karna berbagai hal maka pendidik bisa memperbaiki atau menyempurnakan pembelajaran dipertemuan selanjutnya;

b. Jika sarana pendukung kurang lengkap seperti proyektor, kartu dan lain lain bisa dialihkan menggunakan laptop pribadi pendidik dalam menayangkan vidio dan membuat kartu membaca bersama-sama;

c. Jika partisipasi/motifasi belajar siswa /siswi kurang, maka bisa mengadakan permainan/game yang bernuansa pembelajaran untuk meningkatkan semangat peserta didik;

d. Peserta didik diminta membuat catatan pelajaran dengan tujuan agar bisa mengulangnya lagi jika lupa atau kurang paham;

e. Jika peserta didik sakit, bisa meminta catatan kepada teman agar tidak ketinggalan pelajaran.

Kompetensi dasar mata pelajaran Bahasa Indonesia,khususnya aspek membaca untuk anak SD diadaptasi dari standar kompetensi kurikulum sebelumnya yaitu:'Membaca huruf, suku kata, kata, kalimat, paragraf, berbagai teks bacaan, denah, petunjuk, tata tertib, pengumuman, kamus, ensiklopedia, serta mengapresiasi dan berekspresi sastra melalui kegiatan membaca hasil sastra 
berupa dongeng,cerita anak-anak,cerita rakyat,cerita binatang,puisi anak,syair lagu,pantun,dan drama anak. Kompetensi membaca juga diarahkan menumbuhkan budaya baca (Andi Halimah,2014;193).

Dari kompetensi dasar membaca untuk SD, guru dituntut dapat menggunakan metode metode yang kreatif bagi anak agar tujuan pembelajaran dapat tercapai. Guru juga harus mampu memberikan atau menciptakan pendidikan dan pembelajaran yang kondusif dengan penuh tanggung jawab. Guru yang berkualitas akan menghasilkan orang orang hebat. Karna Keberadaan guru menjadi penentu kualitas-mutu pendidikan suatu bangsa. Minister of Education, Culture and Science (2013) guru menjadi penentu kualitas pendidikan. Harapan yang menjadi cita-cita bersama secara langsung maupun tidak langsung diembankan oleh seorang guru (Mustafa, Hermandra, Suarman, \& Zulhafizh, 2019). Maka tidaklah keliru sekiranya dikatakah bahwa profesi guru mampu memberikan peran dan warna dalam konteks pelaksanaan pendidikan.

\section{Simpulan}

Metode K\&V (Kartu \& Vidio) adalah suatu metode pembelajaraan membaca yang melibatkan media kartu dan vidio yang mana metode ini dikhususkan kepada anak SD kelas 1 untuk membantu memperkenalkan lambang lambang / huruf kepada anak dan diharapkan bisa membantu memperlancar membaca anak. Tujuan penulis menginovasi pembelajaran membaca ini adalah karna masi banyak menjumpai anak SD yang belum hafal huruf atau lancar membaca terutama anak SD kelas 1, oleh karna itulah dirancang sebuah metode pembelajaran yang diharapkan dapat memberikan kemudahan kepada guru sebagai pendidik dan siswa sebagai peserta didik. Pembelajaran membaca yang menarik dapat membuat siswa/siswi tertarik dan suka belajar membaca. Tindakan yang harus dilakukan pendidik yaitu: a. Menjalin komunikasi yang baik dalam pembelajaran; b. Memperkenalkan metode $\mathrm{K} \& \mathrm{~V}$ kepada peserta didik; c.Menerapkan metode K\&V kepada peserta didik; d. Memberikan kuis membaca Kepada peserta didik. 


\section{Referensi}

Metode pembelajaran membaca dan menulis permulaan di SD/MI file:///C:/Users/ACER/AppData/Local/Temp/550-1007-1-SM-1.pdf

Halimah,A.(2014). Metode Pembelajaran Membaca Dan Menulis Permulaan Di Sd/Mi. AULADUNA, VOL. 1 NO. 2 DESEMBER 2014: 190-200.

Komunikasi pendidik dan peserta didik dalam pendidikan islam https://jurnal.iainkediri.ac.id/index.php/mediakita/article/viewFile/365/248

Aziz,A.(2017). Komunikasi Pendidik Dan Peserta Didik Dalam Pendidikan Islam. Mediakita,Vol. 1 No. 2 Juli 2017, 173-184 .

Mustafa, M. N., Hermandra, Suarman, \& Zulhafizh. (2019). Manajerial Pembelajaran Kreatif: Menjadi Guru Jitu. Yogyakarta: Mirra Buana Media.

Motivasi, sikap, dan hasil belajar http://103.216.87.80/index.php/bsp/article/viewFile/4991/3943

Zulhafizh, Atmazaki, \& Syahrul, R. (2013). Kontribusi Sikap dan Motivasi Belajar Siswa terhadap Hasil Belajar Bahasa Indonesia. Jurnal Bahasa, Sastra dan Pembelajaran, 1(2), 13-28.

Minister of Education, Culture and Science. (2013). Exploration: Being a Teacher. Den Haag: Education Council, The Hague. 


\section{*Data Penulis}

Istiqoma Helmi Putri, lahir di Tanjung Pisang, 17 Mei 2002. Pada tahun

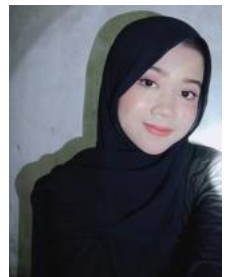
akademik 2020 - 2021 Ia melanjutkan studi pada strata satu Jurusan Pendidikan Bahasa dan Seni di Program Studi Pendidikan Bahasa dan Sastra Indonesia FKIP Universitas Riau melalui jalur PBUD (Penulusuran Bibit Unggul Daerah).

\section{Kontak:}

Hp/WA : 082287300361

Email : istiqoma.helmi6854@student.unri.ac.id 